\title{
Practical Teaching Reform on Computational Thinking Training for Undergraduates of Computer Major
}

\author{
Jian-Bin Ma \\ Agricultural University of Hebei, CHINA \\ Gui-Fa Teng \\ Agricultural University of Hebei, CHINA \\ Gui-Hong Zhou \\ Agricultural University of Hebei, CHINA \\ Chen-Xia Sun \\ Agricultural University of Hebei, CHINA
}

Received 7 July 2017 - Revised 11 September 2017 - Accepted 1 October 2017

\begin{abstract}
To improve undergraduates' practical ability, strengthen their computational thinking training, and meet the social requirements for computer talents, Agricultural University of Hebei (AUH) in China has reformed practical teaching for computer major since 2013. Practical ability training program is made to guide the practical teaching reform. The reform includes four aspects, i.e. project-driven teaching methods, teaching staff construction, teaching support platform, and creative ability training methods. After implementing the reform for several years, AUH have achieved satisfying results. In this paper, the concrete contents and measures of the reform is introduced to provide reference to other colleges and universities.
\end{abstract}

Keywords: practical teaching reform, computational thinking, computer major, colleges and universities

\section{INTRODUCTION}

With the development of computer technology, many colleges and universities in the world have set up computer major. There are more than 800 colleges and universities that have computer major in China. In recent years, computer education in Chinese colleges and universities has some serious problems. On the one hand, computer major graduates cannot find suitable jobs; on the other hand, employers cannot find high-end computer professionals (Liu, 2015). Some reasons lead to the problems. Firstly, colleges and universities do not train enough practical ability for computer major undergraduates. Colleges and universities pays attention to classroom teaching, but the practice teaching is not standard. Secondly, practice teaching method is unitary. Theory cannot be linked with practice. Thirdly, colleges and universities just instill computer knowledge, but they do not pay attention to developing undergraduates' thinking modes of solving problems with computers. Computer technology develops rapidly. Because computer major graduates lack computational thinking habits, it is difficult for computer major graduates to meet the requirement of the times.

(C) Authors. Terms and conditions of Creative Commons Attribution 4.0 International (CC BY 4.0) apply. Correspondence: Jian-Bin Ma, Assistant Professor, College of Information Science and Technology, Agricultural University of Hebei, China. Address to No.289, Lingyusi St., Lianchi Dist., Baoding City 071001, China. Tel: +86-03127526425. 


\section{Contribution of this paper to the literature}

- The contents and measures of practical teaching reform in AUH are proposed to train computational thinking ability for computer major undergraduates.

- A practical ability training program is made to guide the practical teaching reform.

- Four aspects of the practical teaching reform including project-driven teaching methods, teaching staff construction, teaching support platform, and creative ability training methods are introduced.

The practical teaching plays an important role in the whole teaching process in colleges and universities. Practical teaching can help undergraduates improve comprehensive quality, enhance practical ability and cultivate creative spirit. Graduates with strong practical ability are welcomed by employment institutions. So, practical ability training attracts colleges and universities' attention (Bhurtun, 1999; Du, 2011; Ran, 2010).

Computational thinking is first proposed by Jeannette Wing (Wing, 2006). It is a set of thinking skills, habits and approaches for problem-solving using computers (Lee, 2011). Computational thinking is a fundamental skill for everyone (Guzdial, 2008). Researchers has explored methods that infuse computational thinking into K-12 teaching (Allan, 2010; Barr, 2011; Settle, 2012). Hambrusch (Hambrusch, 2009) opened "Computational Thinking" courses for science major undergraduates. It is necessary to train students to obtain the ability of computational thinking in the daily teaching process. For computer major undergraduates, computational thinking ability is an elementary quality. However, colleges and universities pay attention to impart knowledge; the training of computational thinking is often neglected.

Computer major of Agricultural University of Hebei (AUH) in China was established in 1994. AUH is one of the earliest authorized institutions of computer major in agricultural colleges and universities in China. In order to adapt to the AUH's orientation of "joining mainstreams and having characteristics", train high-quality talents which are applied, complex and personalized, strengthen undergraduates' thinking ability, practical ability and creative ability, practical teaching of the computer major in AUH has been reforming since 2013.

\section{THE PRACTICAL TEACHING REFORM}

The reform aims at improving students' practical ability and strengthening students' computational thinking ability. It is guided by practical ability training program. Project-driven teaching methods and teaching staff construction mechanisms were implemented. Teaching support platform was built. Undergraduates were encouraged to attend scientific research and competition to improve their creative ability. The ideas of practical teaching reform are shown in Figure 1. 


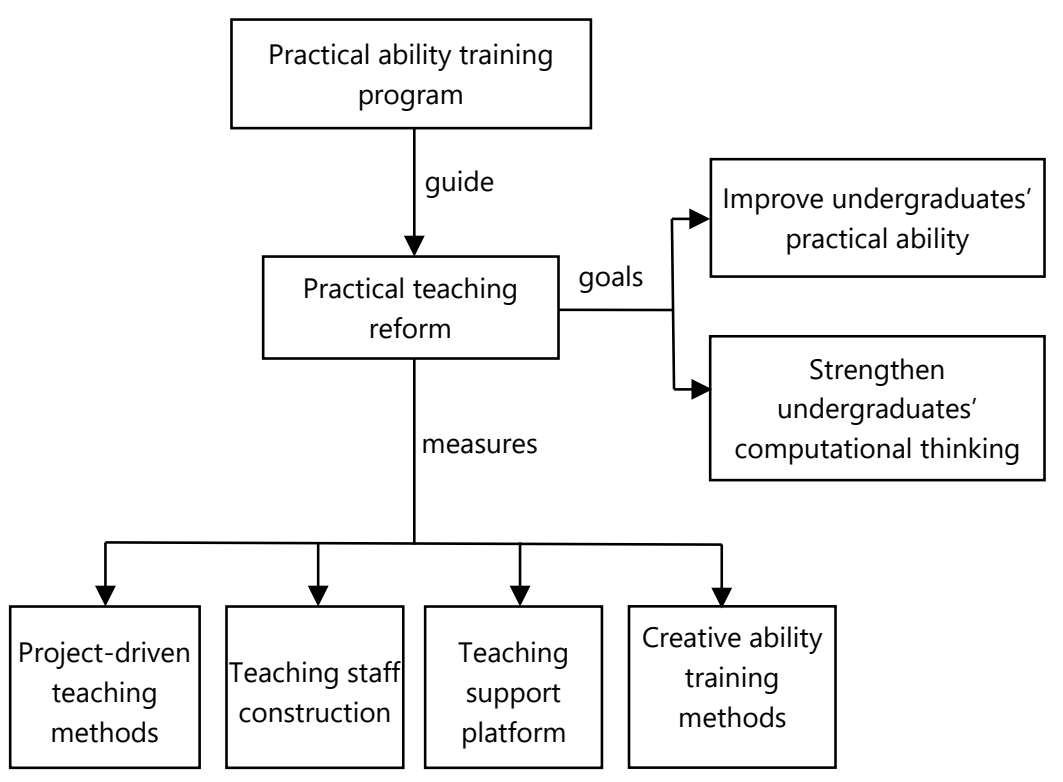

Figure 1. The ideas of practical teaching reform

\section{Practical Ability Training program}

The objective of practical ability training program is to cultivate practical talents with solid practice ability, computational thinking ability and creative ability. The training program follows four principles.

(1) Meet the employment and social needs. The arrangement of computer professional curriculum and teaching contents is to enable undergraduates to have the ability to meet the future employment and social needs.

(2) Strengthen practical teaching contents. To improve undergraduates' practical ability, extensive practical teaching contents such as experimental courses, curriculum designs, integrated practical training courses, graduation practice, graduation project and university-enterprise training are arranged.

(3) Strengthen the university-enterprise cooperation. The idea of university-enterprise cooperation is to set up practice bases in enterprises. Undergraduates go to the enterprise to practice. Universityenterprise cooperation realizes the seamless connection between undergraduates and employment institutions, so as to improve their employment opportunities.

(4) Reforming the teaching system of computer courses. Based on the ideas of computational thinking, the target of the reform of teaching system is to cultivate undergraduates' sustainable development ability of computer application technology, promote their professional innovation ability.

Practical ability training program divides the training ability into three parts, i.e. basic ability, major core ability and expanding ability. The three abilities are subdivided into other abilities. The detail of ability partition in practical ability training program is shown in Figure 2. 


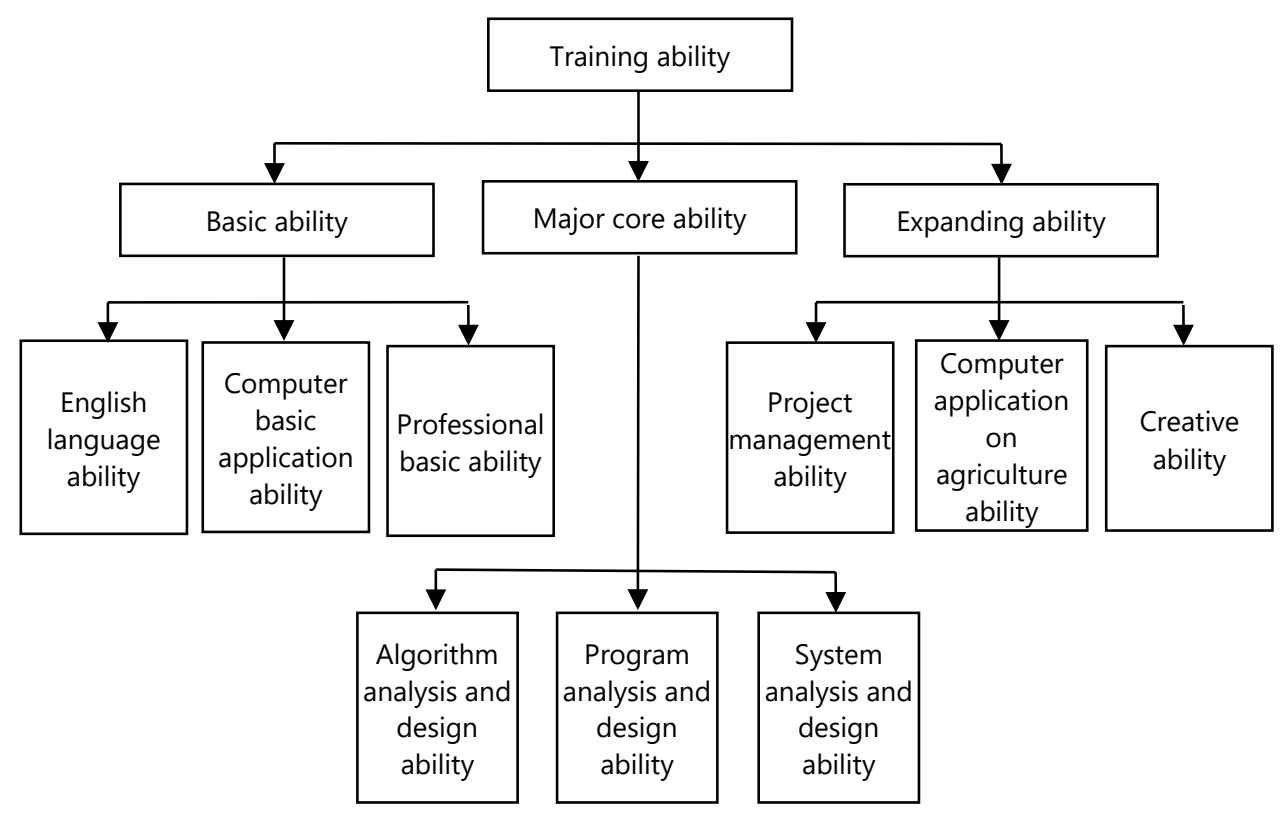

Figure 2. The ability partition in practical ability training program

The idea of computational thinking is to cultivate the habit of learning and thinking, and to improve undergraduates' innovative ability. The practical ability training program follows "skill-knowledge-thinking" three layers educational ideas. The computational thinking training runs through the whole process of the practical ability training program. In the stage of basic ability training, undergraduates establish formal, model description and abstract thinking. In the stage of major core ability training, undergraduates further consolidate and improve the computational thinking ability. In the stage of expanding ability training, undergraduates solve complex engineering problems using computational thinking ability. The corresponding curriculum arrangement is carried out step by step from three aspects, namely, undergraduates' quality training, thinking training and creative ability training, so as to achieve the reform goal of improving students' thinking ability and creative ability.

The teaching arrangement adopts " $3+1$ " talents training mode, which divides four years in university into two stages. The first stage is the first three years. The undergraduates need to complete all the courses that the syllabus requires and they should have certain theoretical and technical knowledge. Then the last one year is the second stage. In the second stage, undergraduates practice in the enterprises and finish curriculum training, comprehensive training, graduation practice, and graduation project. The purpose of the teaching arrangement is to strengthen undergraduates' practical ability, seamlessly connect the undergraduates with employment institutions.

\section{Project-driven Teaching Methods}

Computational thinking emphasizes problem-solving methods and thinking. In order to strengthen computational thinking training, the traditional teaching methods including book centered, classroom centered and teacher centered need to be changed. Undergraduate centered, autonomous, cooperative project-driven teaching methods should be explored.

Project-driven teaching focuses on developing undergraduates' thinking methods and processes of problem-solving using basic concepts of computer science. The purpose of project-driven teaching is to enable undergraduates to gradually improve their computational thinking ability in the process of project realization. 


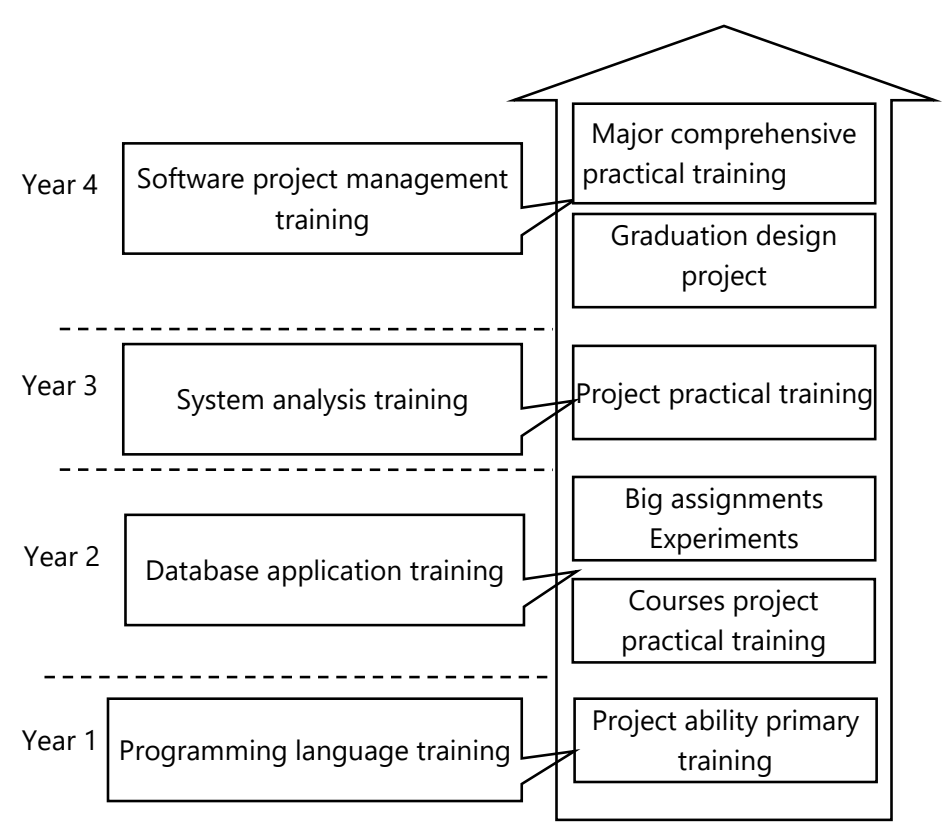

Figure 3. The project-driven implementation plans

Problem-solving using computational thinking follows progressive thinking processes, i.e. "Observation $\rightarrow$ Association $\rightarrow$ Transformation". Take project of "license plate recognition" as an example, teachers guide undergraduates according to the project development process in their teaching. Firstly, let undergraduates "see" the case, i.e. requirement analysis, figure out the tasks that the project need to solve, for example, the above project should determine the position of the car's license plate, recognize characters, letters and digits. Secondly, undergraduates abstract the project based on "Association" thinking, which means that undergraduates abstract the processes that computer can solve, for example, the project can be abstracted as "Image acquisition $\rightarrow$ License plate area location $\rightarrow$ Character segmentation $\rightarrow$ Character recognition $\rightarrow$ Results output". Finally, undergraduates realize the project using Charge-coupled Device (CCD) to collect images, image segmentation and image recognition algorithm to realize the function modules after "Transformation" thinking. By problem-solving processes in the project, undergraduates can understand how the computer collect, store, represent and process the information, so as to train the undergraduates' computational thinking ability.

Up to now, the project case library including more than 30 project cases of computer related has been established in AUH. Project-driven runs through the whole four years undergraduates teaching. The project-driven implementation plans are shown in Figure 3.

\section{Teaching Staff Construction}

Teaching staff is the key factor to train undergraduates' computational thinking. In AUH, through overseas training, in-service studies, academic exchanges, professional training and other ways to strengthen teachers' understanding of the concept of computational thinking, and enhance the professional level of teaching staff.

More than $30 \%$ of teachers in AUH that are engaged in computer teaching have experience of studying in overseas. Through overseas studying, they broaden their outlook, improve their professional knowledge and strengthen their bilingual teaching ability. 
Computer science and technology develop rapidly. In order to learn frontier knowledge and advanced technology, many teachers are organized to visit some famous software companies such as Microsoft, IBM, Oracle, HUAWEI etc, some famous experts at home and abroad are invited to give lectures to teachers.

Project-driven teaching brings forward higher requirements to the teachers. Two schemes i.e. "going out" and "bringing in" are adopted to strengthen their professional ability. "Going out" refers to send teachers to study or train in other famous universities or enterprises regularly. "Bringing in" refers to employ technicians from software companies to develop concentrated training for teachers.

\section{Teaching Support Platform}

To guarantee the implementation of practical ability training program, AUH strengthen teaching support platform construction including hardware and software construction in laboratory and university-enterprise training base construction.

\section{Laboratory construction}

Excellent laboratory condition is an important factor to train undergraduates' practical ability and computational thinking ability. In recent years, AUH increased funding for laboratory construction of computer major. Now, there are seven advanced laboratories, i.e. embedded application development laboratory, Java/Android application development laboratory, IOS application development laboratory, distributed laboratory, software engineering laboratory, computer network laboratory and computer component principle laboratory.

Laboratory construction not only concerns hardware equipment, but also pays attention to software configure. Seven experimental teaching platforms and one professional training project management platform were constructed.

Teaching of experimental courses and other practical activities including curriculum designs, graduation designs, and extracurricular innovation competition are arranged in the laboratories.

\section{University-enterprise training base construction}

In order to improve undergraduates' practical ability and vocational adaptability, university-enterprise cooperation has become an effective way to train high-quality and highly skilled talents in colleges and universities. University-enterprise cooperation talents training mode take the enterprise demand and undergraduates qualified for the enterprise's work as the main goal, make teaching plans on the basis of the enterprises' actual production and business activities, and carry out teaching activities in various forms by universities and enterprises. AUH has explored flexible and diverse forms of university-enterprise cooperation.

(1) IT educational enterprise courses training

AUH and the outside well-known IT education enterprises make training plan together, launch software and hardware technology, project management and software skills training courses. We have ever cooperated with Microsoft IT Academy and Intel Software College.

Microsoft IT Academy launched a new globally oriented IT education system, utilized strong technical advantage of Microsoft Corporation, provided high-end IT technology for global teachers and undergraduates in colleges and universities. Microsoft IT Academy train 2 to 3 main courses to computer major undergraduates in AUH annually. The Intel software college provides software and hardware technology courses, project management and software skills training courses based on Intel platform. AUH actively seek cooperation with domestic software corporations. We cooperated with Suodi education institution to provide professional skills training, cooperated with Uplooking Technology Company Limited to provide Android mobile phone 


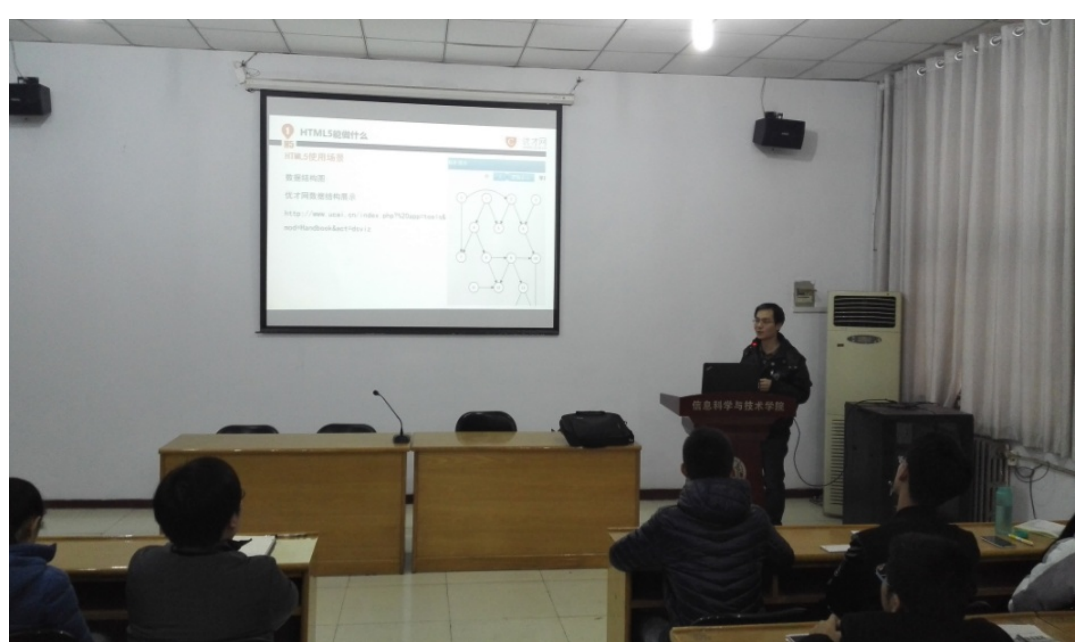

Figure 4. The figure of IT education enterprises training

development and Embedded development, cooperated with Zhuoweida company to provide training of PHP project development.

Through cooperation with well-known software companies, it is helpful for students to access to new IT technology, improve practical ability and increase job opportunities. Figure 4 shows that IT education enterprises are training in $\mathrm{AUH}$.

(2) Send teachers to train in the enterprise

Teachers are sent to train in the enterprises in a planned way. They participate in the project development in enterprises. This measure accelerates the renewal of teachers' knowledge and improves the professional level of teachers. 3 to 5 teachers of computer major are sent to enterprises to train annually in AUH. Through the professional training of teachers, we strive to achieve what businesses need, teachers are proficient in what, and undergraduates know what.

(3) Construct external practice and training bases

AUH actively construct stable practice and training bases of computer major. Undergraduates are really sent to IT enterprises according to the enterprises' software development process and management mode. They can see how the actual operation of the software company. Undergraduates' interest and employment competitiveness are improved.

The practical ability training program arranges 4 weeks of comprehensive training in the seventh semester. Undergraduates increase their practical ability and improve their combat experience through practical training from external training bases. Undergraduates, enterprises and universities achieve mutual benefit from universityenterprise cooperation. At present, AUH has 8 fixed external training bases and is still trying to contact software companies to build more external practice and training bases. Figure 5 shows that undergraduates are training in external training bases. 


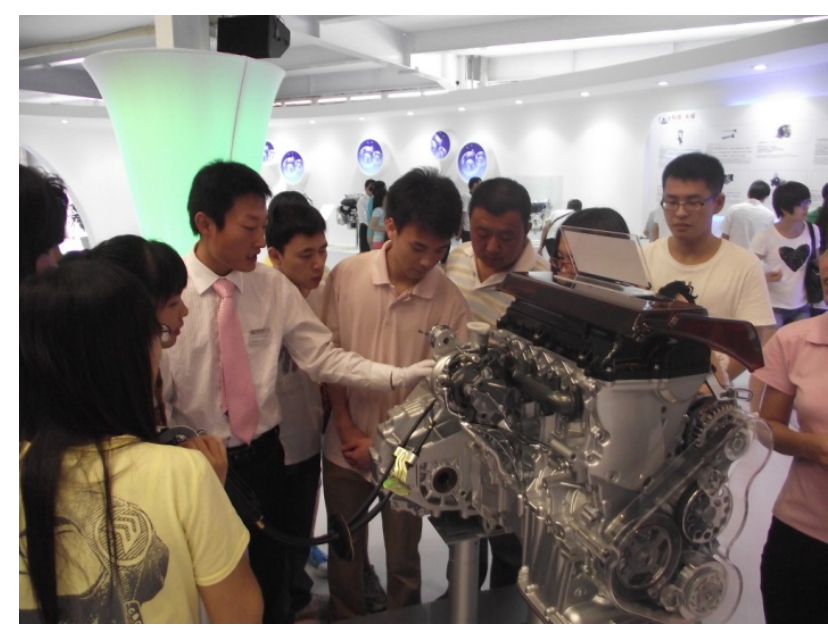

Figure 5. The figure of undergraduates' external training

(4) Construct internal practice bases

Another form of university-enterprise cooperation is to invite enterprises into the university. University and enterprise construct internal practice bases in universities together. External practice and training in enterprises is undoubtedly a better form of university-enterprise training. But, enterprises are not laboratories of the university. It is impossible and unable to accept all the undergraduates. For most undergraduates, constructing internal practice bases in universities, taking the enterprises' project to finish in internal practice bases, creating simulated enterprises environment through the cooperation projects, also can achieve the effect of external practice and training.

\section{Creative Ability Training Methods}

The purpose of innovative education is to arouse the undergraduates to think on their own initiative, train undergraduates' ability to discover problems and solve problems. The objectives of practical ability training program are to train undergraduates' computational thinking, eventually increase their creative ability.

In the daily process of teaching, the idea is to guide undergraduates to solve the problem and conduct system design using the basic concepts, to enable undergraduates to understand the basic ideas of solving natural and social problems, and to develop undergraduates' creative thinking. In addition, utilizing modern teaching methods such as project-driven teaching methods, teaching support platform, combining stimulated approach such as scientific research and competition, the computational thinking ability and creative ability of computer major undergraduates has been significantly improved.

\section{Encourage undergraduates to attend teachers' research projects}

In $\mathrm{AUH}$, a mechanism that undergraduates are integrated into teachers' projects has been formed and inherited. The scientific research projects have stimulated undergraduates' learning interest, improved undergraduates' professional core competence and innovative ability, and enriched the project case library.

\section{Guide undergraduates to attend computer competition}

The competition is to organize undergraduates to attend science and technology activities using learned professional knowledge to examine their basic theoretical knowledge and their ability to solve practical problems. Competition activities can stimulate undergraduates' strong interest in science, and also enhance their practical ability, cooperation spirit and creative ability. 


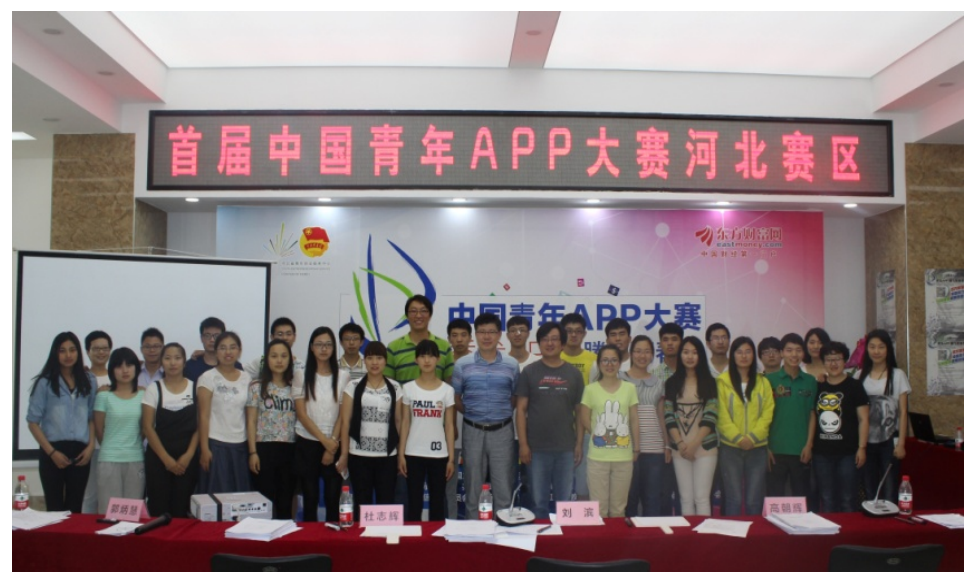

Figure 6. The figure of undergraduates attending the first youth APP competition in China

In recent years, undergraduates have participated in various forms of Computer Applications Competition, Computer Design Competition, Innovation and Entrepreneurship Competition etc and won many awards. Figure 6 shows that undergraduates attend the first youth APP competition in China.

\section{THE EFFECT OF PRACTICAL TEACHING REFORM}

After years of practical teaching reform, the quality of talents training is promoted. The practical ability, computational thinking ability and creative ability of undergraduates of computer major are improved. The talents with more practical ability and creative ability are highly favored by employment institutions. The employment rate and quality of employment increase obviously. In recent years, the employment rate of undergraduates of computer major exceeds $95 \%$. Many graduates have been recruited by companies such as Baidu, Microsoft, Sina, Lenovo, 360, and Jingdong.

\section{CONCLUSION}

Computer related work requires high practical skills. To improve the employment rate of undergraduates of computer major, AUH in China has reformed the practical teaching for computer major. The goal of the reform is to improve undergraduates' practical ability and strengthen their computational thinking training. The guideline document for reform, i.e. practical ability training program is made. The reform starts from four sides, which are project-driven teaching methods, teaching staff construction, teaching support platform, and creative ability training methods. Concrete reform contents and measures are introduced. Many years of teaching reform practice has achieved satisfactory results, which proves that the direction of our practical teaching reform for computer major is right.

\section{ACKNOWLEDGEMENTS}

This research was financially supported by the Department of Education of Hebei Province (Grant No. 1009032).

\section{REFERENCES}

Allan, V., Barr, V., Brylow, D., \& Hambrusch, S. (2010). Computational thinking in high school courses. Sigcse Proceedings of Acm Technical Symposium on Computer Science Education, 17(10), 390-391.

Barr, V., \& Stephenson, C. (2011). Bringing computational thinking to k-12: what is involved and what is the role of the computer science education community? Acm Inroads, 2(1), 48-54. 
Bhurtun, C., Jahmeerbacus, I., Oolun, K., \& Feliachi, A. (1999). Short-term practical training for electrical engineering undergraduates. IEEE Transactions on Education, 42(2), 109-113.

Du, J., Ye, Q., Wen, Q., \& Xiong, K. (2011). The research of introducing project practice training mode for computer professional talent. Procedia Engineering, 15, 4300-4304.

Guzdial, M. (2008). Education paving the way for computational thinking. Communications of the Acm, 51(8), 25-27.

Hambrusch, S., Hoffmann, C., Korb, J. T., Haugan, M., \& Hosking, A. L. (2009). A multidisciplinary approach towards computational thinking for science majors. ACM Technical Symposium on Computer Science Education, 41, 183-187.

Lee, I., Martin, F., Denner, J., Coulter, B., Allan, W., \& Erickson, J. (2011). Computational thinking for youth in practice. Acm Inroad, 2(1), 32-37.

Liu, J., \& He, L. (2015). Practical skills training in computer education. International Journal of Information $\mathcal{E}$ Computer Science, 4, 25-29.

Ran, Z. (2010). Exploration on the key Issues of Practical Teaching Reform of Computer Network. Third International Conference on Education Technology and Training, 17, 1914-1919.

Settle, A., Franke, B., Hansen, R., Spaltro, F., Jurisson, C., Rennert-May, C., \& Wildeman, B. (2012). Infusing computational thinking into the middle- and high-school curriculum. Proceedings of the 17th ACM annual conference on Innovation and technology in computer science education, 22-27.

Wing, J. (2006). Computational thinking. Communications of the ACM, 49(3), 33-35.

\section{http://www.ejmste.com}

